\title{
Long-Term Manuring and Fertilization Effects on Soil Physical Properties after Forty Two Cycles under Rice-Wheat System in North Indian Mollisols
}

\author{
Pawan Kumar Pant* and Shri Ram
}

Department of Soil Science, College of Agriculture, G.B. Pant University of Agriculture \& Technology, Pantnagar, U.S. Nagar, Uttarakhand, 263145, India

*Corresponding author

\section{Keywords}

Long-term fertilizer experiment,

Physical properties, Rice-Wheat sequence, Mollisols

Article Info

Accepted:

04 June 2018

Available Online:

10 July 2018

\section{A B S T R A C T}

An investigation was carried out at Norman E. Borlaug Crop Research Centre of G. B. Pant Univ. Agric. \& Tech. Pantnagar, U. S. Nagar, Uttarakhand, India in order to study the influence of long-term applications of fertilizers and manures on different soil physical properties after forty two cycles in silty clay loam textured Typic Haplustept under ricewheat cropping sequence during 2012-13. The field was laid out in a randomized block design comprising of ten treatments. Various soil physical properties were measured in surface and sub-surface soil after harvest of rice and wheat crops after 42 cycles and it was found that in $0-60 \mathrm{~cm}$ soil layers, the bulk density was significantly lower in $100 \%$ NPK + FYM over other treatments. The balanced application of NPK decreased the bulk density in all the soil depths. Irrespective of soil depths, the control plot invariably showed higher bulk density. The soil receiving 100\% NPK fertilizers with FYM recorded significantly higher hydraulic conductivity, water holding capacity and mean weight diameter in soils of all four depths, respectively as compared to control and all other fertilizer treatments. Application of $\mathrm{P}$ in combination with $\mathrm{N}$ significantly increased the hydraulic conductivity in comparison to where $\mathrm{N}$ was applied alone. Mean weight diameter increased with increasing fertilizer dose from sub optimal 50\% NPK to 100\% NPK optimal dose of NPK. The present investigation clearly points out the significance of balanced use of nutrients including FYM in rice-wheat cropping system for improving the various physical soil properties over a long period.

\section{Introduction}

Rice-wheat cropping system is the world's largest most prominent cropping system occupying around $12.3 \mathrm{M}$ ha in India around 85 percent of this area falls in Indo-Gangetic plains (Ladha et al., 2003). The Indo-Gangetic plains region of India has Rice-wheat cropping sequence spread over a vast area from Punjab in the Northwest to East up to West Bengal (Singh et al., 2005). The deterioration of soil physical heath due to continuous cultivation without acceptable replenishment poses an immediate threat to soil health and environmental securities. Continuous cultivation of crops and excessive use of fertilizers is depleting the soil physical health hence, there is a need to reintroduce the 
age old practice of application of farmyard manure (FYM) to maintain soil fertility as well as soil health and also to supplement many essential plant nutrients for crop productivity.

Integrated nutrient management practices have come up as effective options in restoring the soil physical properties and chemical fertility as well as improving the organic matter in the soil (Rudrappa et al., 2006; Nayak et al., 2012). Balanced use of fertilizers in combination with manures is one of the best ways to prevent organic matter depletion and rapid deterioration of soil physical properties, specially soil structure (Singh et al., 2007). Addition of organic matter increases soil organic carbon content, which directly or indirectly affects physical properties of soil and processes like aggregation, water-holding capacity (WHC), hydraulic conductivity and bulk density (Zebarth et al., 1999; Celik et al., 2004). While improvement in soil structural condition through the addition of $\mathrm{C}$ inputs has been profusely reported, a quantitative evaluation of soil physical properties under integrated nutrient management system.

The physical soil quality parameters like bulk density, water holding capacity, hydraulic conductivity and mean weight diameter of soil were improved in rice-wheat cropping system because of use of inorganic fertilizer in combination with FYM over a period of forty two years. Thus, the balance and imbalanced use of nutrients through and organic manures and chemical fertilizers should be followed for the improvement of physical soil quality for sustainability (Pant et al., 2017). While the consequence of excessive use of mineral fertilizers adversely affected soil physicochemical properties, which ultimately reduces the productivity as well as physical environment of soil under rice-wheat cropping system (Kakraliya et al., 2017). Organic manure along with mineral fertilizer also helps to build up soil organic matter, which increases organic carbon which improves soil aggregation and its stability, reduce soil compaction, increase porosity and water holding capacity. Therefore, Long-term fertilizer experiments running on a Typic Haplustept with rice-wheat cropping sequence in G. B. Pant Univ. Agric \& Tech. Pantnagar, since 1971 become a useful study material for soil physical properties under mollisols.

\section{Materials and Methods}

\section{Experimental design}

A field experiment was carried out during 2012-13 in an ongoing Long-Term Fertilizer Experiment conducted with a rice- wheat cropping sequence that have been operative since 1971 at Norman E. Borlaug Crop Research Centre of G.B. Pant Univ. Agric. \& tech. Pantnagar, U. S. Nagar, Uttarakhand $\left(29^{0}\right.$ $\mathrm{N}$ latitude, $79^{\circ} 29^{\prime} \mathrm{E}$ longitude and an altitude of $243.8 \mathrm{~m}$ above the mean sea level), consisted of 12 fertilizer treatments, out of which 10 treatments have been selected for the study (Table 1).

The fertilizer N, P and K were applied through urea/diammonium phosphate, Single Super Phosphate and muriate of potash, respectively. Farmyard manure applied once in a cropping cycle, each year before the sowing of wheat crop. The fertilizer dose was selected based on the soil tests for available $\mathrm{N}, \mathrm{P}$ and $\mathrm{K}$ in the year 1971. Each treatment was replicated three times (plot size $25 \mathrm{~m} \times 12.5 \mathrm{~m}$ ) in a randomized block design.

\section{Climate and weather conditions during experimental seasons}

The Climate of Pantnagar falls under the subhumid and sub-tropical climatic zones with hot dry summers and cool winters. Generally, southwest monsoon sets in third or fourth 
week of June and continues upto end of September with its peak in July. Weekly mean maximum and minimum temperature ranged from 34.5 to $11.9^{\circ} \mathrm{C}$ during rice crop in 2012 and 35.6 to $2.5^{\circ} \mathrm{c}$ during wheat crop in 201213. The mean weekly relative humidity during rice crop ranged from 94 to 35 percent and 99.6 to 12.9 percent during wheat crop. Total rainfall received during the cropping period of rice was $873.8 \mathrm{~mm}$ and $173.5 \mathrm{~mm}$ during wheat crop.

\section{Crop cultivation}

Rice variety 'PR113' was used for this study. Seedlings of rice were raised by wet bed method of nursery. Seed beds were prepared in dry condition. A day before sowing, the beds were flooded with irrigation water. Sprouted seeds were broadcasted to raise seedlings. Twenty-one days old seedlings were transplanted on first week of July during 2012 at a distance of $20 \mathrm{~cm}$ row to row and 10 $\mathrm{cm}$ plant to plant. Half dose of $\mathrm{N}$ and full dose of $\mathrm{P}$ and $\mathrm{K}$ as per treatment were applied as basal dressing before rice transplanting. The remaining half dose of $\mathrm{N}$ was top dressed in two equal splits, after 3 and 6 weeks of transplanting. The crop was harvested in the month of November after recording the observations.

After harvesting of rice crop, experimental plots were ploughed by tractor drawn disc plough. After one ploughing and 3-4 harrowing the field got leveled by plank and wheat (variety PBW 502) was sown on last week of November during 2012, at a row distance of $23 \mathrm{~cm}$. Half dose of $\mathrm{N}$ and full dose of $\mathrm{P}$ and $\mathrm{K}$ were applied just before sowing. The remaining half dose of $\mathrm{N}$ was applied in two equal splits at first and second irrigation. In T8 treatment, FYM was applied @ $15 \mathrm{t} \mathrm{ha}^{-1}$, before the preparation of field for wheat. Irrigation was done as and when required up to crop maturity.

\section{Soil sampling and processing}

Representative soil samples were collected separately from each treatment in triplicate from the depth increments of 0-15, 15-30 30$45 \mathrm{~cm}$ and 45-60 $\mathrm{cm}$ with the help of core sampler and auger to collect undisturbed soil sample for bulk density, soil hydraulic conductivity, Mean weight diameter whereas 2 $\mathrm{mm}$ sieved soil samples were used for water holding capacity (WHC). The initial soil $\mathrm{pH}$ (1:2.5) was 7.30 , electrical conductivity 0.35

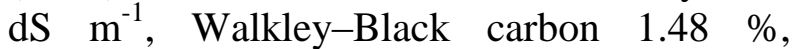
available $\mathrm{N} 392.0 \quad \mathrm{~kg} \quad \mathrm{ha}^{-1}, \quad \mathrm{NaHCO}_{3}-$ extractable $\mathrm{P} 18 \mathrm{~kg} \mathrm{ha}{ }^{-1}$ and $\mathrm{NH}_{4} \mathrm{OAc}-$ extractable $\mathrm{K} 125 \mathrm{~kg} \mathrm{ha}^{-1}$ soil. The soil is of alluvial origin, silty clay loam in texture.

\section{Soil physical properties measurements}

The soil bulk density at desired depths (0-15, 15-30, 30-45 and 45-60 cm) was determined by core sampler method (Blake and Hartge 1986). Water holding capacity of soil was determined by the method enlisted by Piper (1950). The undisturbed soil samples of desired depths were taken by core, and used for determination of hydraulic conductivity by constant head method (Klute, 1965). Air dried solid clods were used for aggregate analysis employing modified Yoder's wet sieving method (Van-Bavel, 1949).

\section{Statistical analysis}

The data were analyzed using Randomized Block Design using SPSS-16. To compare treatment means, least significant difference was worked out at 5\% level of probability.

\section{Results and Discussion}

\section{Bulk density}

The soil bulk density was lower in treatments where balanced fertilization with FYM 
amended treatment was practiced (Fig. 1a and 1b). In $0-60 \mathrm{~cm}$ soil layers, the bulk density was significantly lower in $100 \%$ NPK + FYM over other treatments (Fig. 1a and 1b). The balanced use of NPK decreased the bulk density in all the soil depths. Irrespective of soil depths, the control plot showed higher bulk density.

Bulk density after rice crop ranged from 1.53 to $1.26 \mathrm{~g} \mathrm{cc}^{-1}$ soil in surface soil and 1.61 to $1.34 \mathrm{~g} \mathrm{cc}^{-1}$ in $15-30 \mathrm{~cm}, 1.63$ to $1.44 \mathrm{~g} \mathrm{cc}^{-1}$ in $30-45 \mathrm{~cm}$ and 1.73 to $1.54 \mathrm{~g} \mathrm{cc}^{-1}$ in $45-60 \mathrm{~cm}$ in sub-surface soil, respectively. Treatments $100 \%$ NPK +FYM, $100 \%$ NPK, $100 \%$ $\mathrm{NPK}+\mathrm{H} . \mathrm{W}$, and $100 \% \mathrm{NPK}+\mathrm{Zn}$ recorded significantly less bulk density than the control.

The bulk density exhibited an increasing trend with increase in soil depth $(0-60 \mathrm{~cm})$ in respective treatments. The decrease in bulk density over the years could be due to the addition of root and plant biomass and to the conversion of some micro-pores into macropores because of cementing action of organic acids and polysaccharides which are formed during the decomposition of organic residues by higher microbial activities. The decrease in soil BD under $100 \%$ NPK with organic manure (FYM) mainly contributed to higher organic matter content of the soil because of higher microbial activities which leads to better aggregation of soil. Tripathi et al., (2014) and Pant et al., (2017) also observed that application of FYM along with fertilizers decreases the BD of soil.

\section{Hydraulic conductivity}

A perusal of data in Table 2 indicated that hydraulic conductivity after rice crop ranged from 0.63 to $0.84 \mathrm{~mm} \mathrm{hr}^{-1}$ soil in surface soil and 0.49 to $0.70 \mathrm{~mm} \mathrm{hr}^{-1}$ in $15-30 \mathrm{~cm}, 0.28$ to $0.55 \mathrm{~mm} \mathrm{hr}^{-1}$ in $30-45 \mathrm{~cm}$ and 0.13 to 0.31 $\mathrm{mm} \mathrm{hr}^{-1}$ in $45-60 \mathrm{~cm}$ depth, respectively. Alike after wheat crop, surface soil recorded highest hydraulic conductivity than subsurface soil. In top soil of $0-15 \mathrm{~cm}$ the hydraulic conductivity ranged from 0.65 to $0.91 \mathrm{~mm} \mathrm{hr}^{-1}$ after wheat crop. However, in deeper soil depth hydraulic conductivity ranged from 0.51 to $0.74 \mathrm{~mm} \mathrm{hr}^{-1}$ in $15-30 \mathrm{~cm}$, 0.31 to $0.63 \mathrm{~mm} \mathrm{hr}^{-1}$ in $30-45 \mathrm{~cm}$ and 0.15 to $0.38 \mathrm{~mm} \mathrm{hr}^{-1} 45-60 \mathrm{~cm}$, respectively.

Maximum value of hydraulic conductivity in surface as well as sub-surface soil was observed with $100 \% \mathrm{NPK}+\mathrm{FYM}$ treatment followed by $100 \% \mathrm{NPK}+\mathrm{Zn}$ treatment and the lowest was under control treatment. Application of $\mathrm{P}$ in combination with $\mathrm{N}$ and $\mathrm{Zn}$ improved the hydraulic conductivity in comparison to $\mathrm{N}$ alone treatment. Data indicated that treatments balanced fertilization with FYM markedly improved the hydraulic conductivity due to more organic matter content which increased biological activity, improved soil aggregation, and optimum pore volume as well as the effective connectivity of the pores. Overall hydraulic conductivity showed decreasing trend with increase in soil depth $(0-60 \mathrm{~cm})$ in respective treatments.

As compared to control, hydraulic conductivity increased with the application of fertilizers and improved further by addition of FYM, indicating the beneficial effect on soil properties and the similar findings were also observed by Kaje et al., (2018) and Nandapure et al., (2014).

\section{Water holding capacity}

Data from figure $2 \mathrm{a}$ and $2 \mathrm{~b}$.indicated that soil WHC was maximum in treatments where balanced fertilization with FYM amended treatment was practiced. WHC after harvest of rice crop ranged from 58.35 to $74.97 \%$ in surface soil and 56.57 to $73.19 \%$ in $15-30 \mathrm{~cm}$, 51.73 to $70.09 \%$ in $30-45 \mathrm{~cm}$ and 45.64 to $64.13 \%$ in $45-60 \mathrm{~cm}$ depths, respectively. 
Table.1 Treatment details of long-term field experiment

\begin{tabular}{|l|l|}
\hline Treatment & Details \\
\hline $\mathbf{T}_{\mathbf{1}}$ & $50 \%$ NPK \\
\hline $\mathbf{T}_{\mathbf{2}}$ & $100 \%$ optimum NPK \\
\hline $\mathbf{T}_{\mathbf{3}}$ & $150 \%$ NPK \\
\hline $\mathbf{T}_{\mathbf{4}}$ & $100 \% \mathrm{NPK}+$ Hand Weeding \\
\hline $\mathbf{T}_{\mathbf{5}}$ & $100 \% \mathrm{NPK}+\mathrm{Zn}$ \\
\hline $\mathbf{T}_{\mathbf{6}}$ & $100 \% \mathrm{NP}$ \\
\hline $\mathbf{T}_{\mathbf{7}}$ & $100 \% \mathrm{~N}$ \\
\hline $\mathbf{T}_{\mathbf{8}}$ & $100 \% \mathrm{NPK}+\mathrm{FYM}$ \\
\hline $\mathbf{T}_{\mathbf{9}}$ & $100 \%$ NPK $(-\mathrm{S})$ \\
\hline $\mathbf{T}_{\mathbf{1 0}}$ & control-no NPK or manure \\
\hline
\end{tabular}

Table.2 Effect of fertilizer treatments on soil hydraulic conductivity $\left(\mathrm{mm} \mathrm{hr}^{-1}\right)$ after rice-wheat cropping system

\begin{tabular}{|c|c|c|c|c|c|c|c|c|}
\hline \multirow[t]{3}{*}{ Treatments } & \multicolumn{8}{|c|}{ Soil hydraulic conductivity $\left(\mathrm{mm} \mathrm{hr}^{-1}\right)$} \\
\hline & \multicolumn{4}{|c|}{ Rice crop } & \multicolumn{4}{|c|}{ Wheat crop } \\
\hline & $\begin{array}{l}\text { 0-15 } \\
\text { cm }\end{array}$ & $\begin{array}{c}15-30 \\
\mathrm{~cm}\end{array}$ & $\begin{array}{c}30-45 \\
\mathrm{~cm}\end{array}$ & $\begin{array}{c}45-60 \\
\mathrm{~cm}\end{array}$ & $\begin{array}{c}0-15 \\
\text { cm }\end{array}$ & $\begin{array}{c}15-30 \\
\mathrm{~cm}\end{array}$ & $\begin{array}{c}30-45 \\
\mathrm{~cm}\end{array}$ & $\begin{array}{c}45-60 \\
\mathrm{~cm}\end{array}$ \\
\hline $50 \% \quad$ NPK & 0.74 & 0.60 & 0.45 & 0.21 & 0.75 & 0.64 & 0.47 & 0.28 \\
\hline $100 \%$ NPK & 0.76 & 0.62 & 0.47 & 0.23 & 0.78 & 0.67 & 0.52 & 0.31 \\
\hline $150 \%$ NPK & 0.77 & 0.63 & 0.48 & 0.24 & 0.79 & 0.68 & 0.54 & 0.32 \\
\hline $100 \%$ NPK+H.W. & 0.78 & 0.64 & 0.49 & 0.25 & 0.79 & 0.67 & 0.54 & 0.31 \\
\hline $100 \% \mathrm{NPK}+\mathrm{Zn}$ & 0.79 & 0.65 & 0.50 & 0.26 & 0.81 & 0.69 & 0.56 & 0.33 \\
\hline $100 \% \mathrm{NP}$ & 0.77 & 0.63 & 0.48 & 0.24 & 0.80 & 0.68 & 0.57 & 0.32 \\
\hline $100 \% \mathrm{~N}$ & 0.71 & 0.57 & 0.42 & 0.18 & 0.73 & 0.63 & 0.49 & 0.27 \\
\hline $100 \%$ NPK+FYM & 0.84 & 0.70 & 0.55 & 0.31 & 0.91 & 0.74 & 0.63 & 0.38 \\
\hline $100 \%$ NPK(-S) & 0.74 & 0.60 & 0.45 & 0.21 & 0.76 & 0.63 & 0.46 & 0.27 \\
\hline Control & 0.63 & 0.49 & 0.28 & 0.13 & 0.65 & 0.51 & 0.31 & 0.15 \\
\hline SEm \pm & 0.01 & 0.008 & 0.005 & 0.003 & 0.01 & 0.01 & 0.006 & 0.005 \\
\hline $\mathrm{CD}(5 \%)$ & 0.03 & 0.02 & 0.02 & 0.009 & 0.03 & 0.03 & 0.02 & 0.02 \\
\hline
\end{tabular}




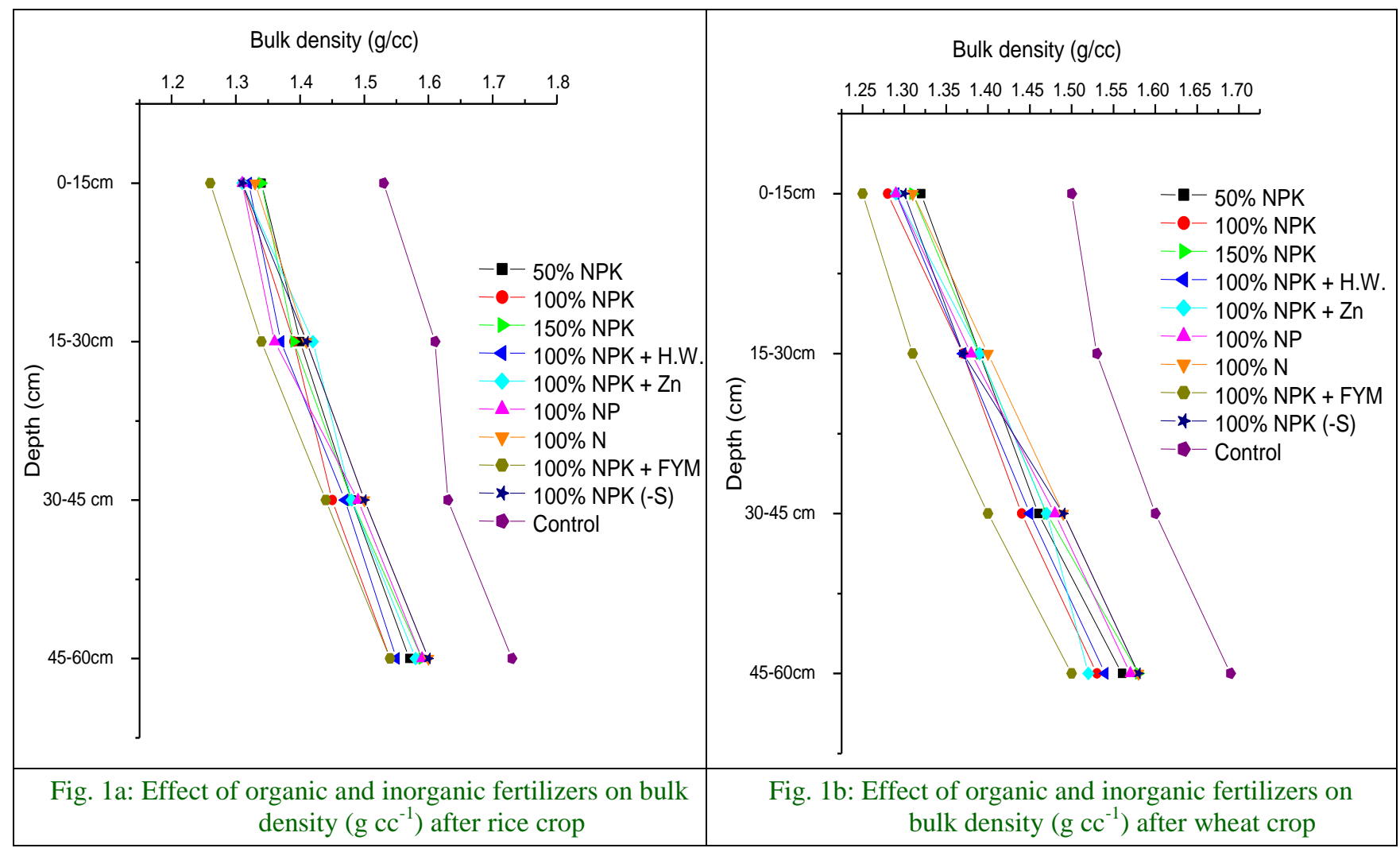

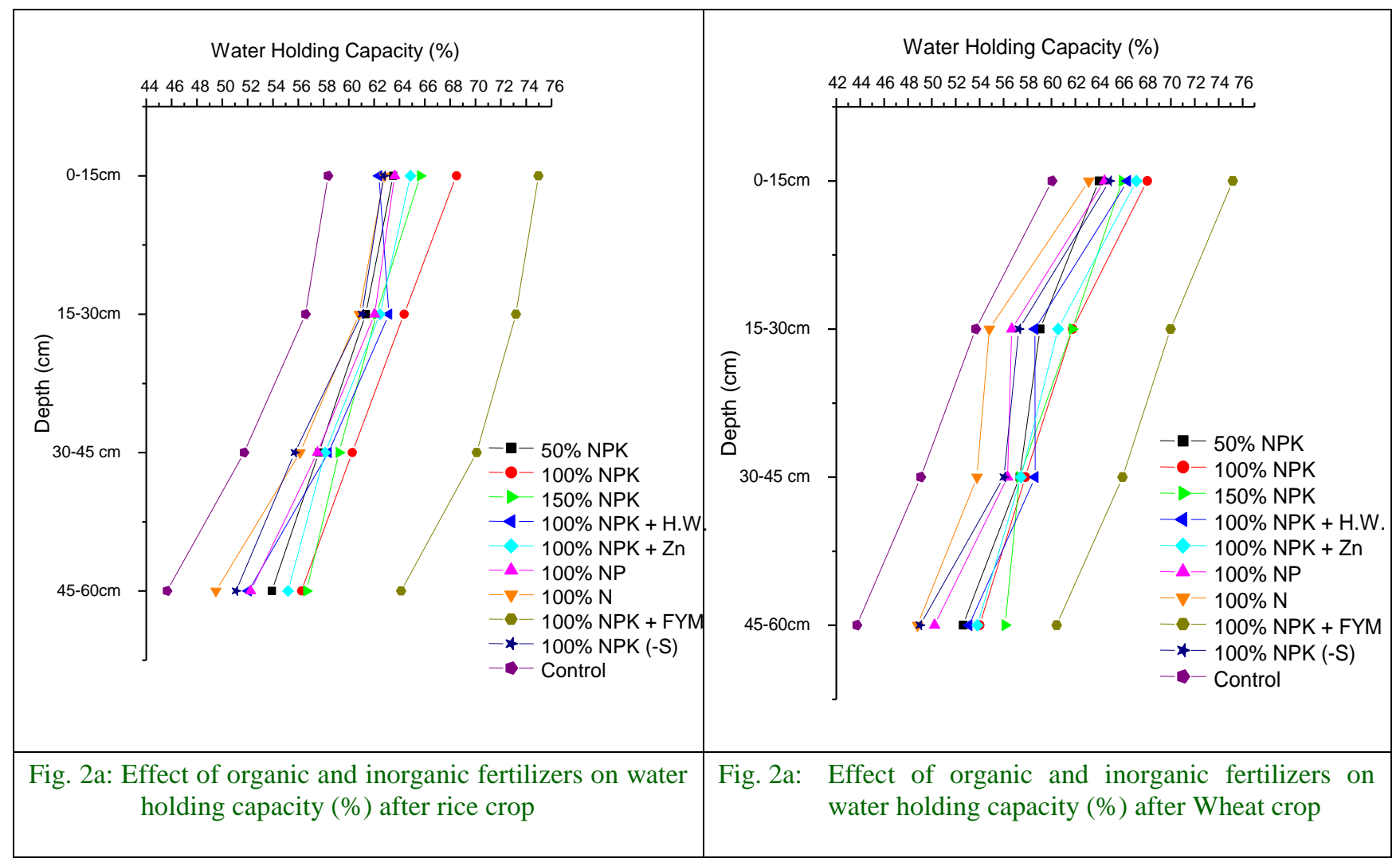




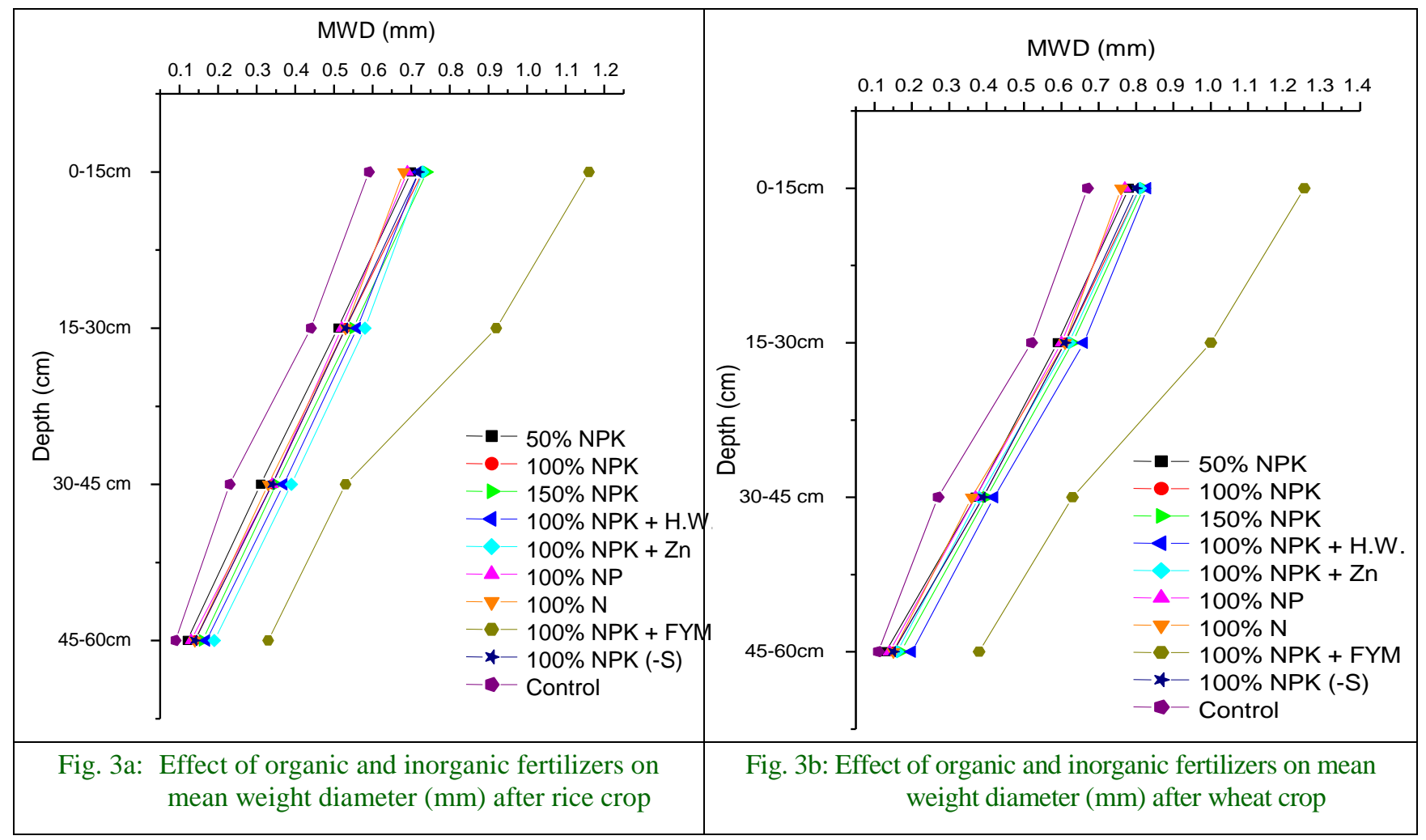

After wheat crop, surface soil recorded highest WHC than sub-surface soil. In top soil of $0-15 \mathrm{~cm}$ the WHC ranged from 60.05 to $75.18 \%$ after wheat crop. However, in deeper soil depth WHC ranged from 53.66 to $69.97 \%$ in $15-30 \mathrm{~cm}, 49.06$ to $65.95 \%$ in $30-45 \mathrm{~cm}$ and 43.71 to $60.43 \%$ in $45-60 \mathrm{~cm}$, respectively.

The lowest WHC values were under control and highest with $100 \%$ NPK+FYM. Treatments of $50 \%$ NPK, $100 \%$ NPK, $150 \%$ NPK, $100 \% \mathrm{NPK}+\mathrm{H} . \mathrm{W}, 100 \% \mathrm{NPK}+\mathrm{Zn}$, $100 \%$ NP and $100 \%$ N recorded significantly higher WHC than the control.

The higher SOC content in FYM treated plots could be responsible for increasing the WHC of the soil, the increase was more in the surface soil layers as compare to lower layers. The higher WHC in the surface layers was due to surface application of FYM which increased the organic carbon level in soil, whereas in the subsurface layers the increase in WHC could be due to the increased root biomass with FYM or inorganic fertilizers (Rasool et al., 2008 and Bhatt et. al, 2017).

\section{Mean weight diameter $(\mathrm{mm})$}

Application of NPK fertilizers @ i.e.50, 100 and $150 \%$ significantly enhanced MWD of soils of surface as well as sub-surface compared to control. Data from figure $3 \mathrm{a}$ and $3 \mathrm{~b}$ indicated that soil MWD was maximum in treatments where balanced fertilization with FYM amended treatment was practiced. The lowest MWD values were under control and highest with $100 \%$ NPK+FYM.

MWD after rice crop ranged from 0.59 to $1.16 \mathrm{~mm}$ in surface soil and 0.44 to $0.92 \mathrm{~mm}$ in $15-30 \mathrm{~cm}, 0.23$ to $0.53 \mathrm{~mm}$ in $30-45 \mathrm{~cm}$ and 0.09 to $0.33 \mathrm{~mm}$ in $45-60 \mathrm{~cm}$ soil depths, respectively. Alike after wheat crop, surface soil recorded highest MWD than sub-surface soil. 
In top soil of $0-15 \mathrm{~cm}$ the MWD ranged from 0.67 to $1.25 \mathrm{~mm}$ after wheat crop. However, in deeper soil depth MWD ranged from 0.52 to $1.00 \mathrm{~mm}$ in $15-30 \mathrm{~cm}, 0.27$ to $0.63 \mathrm{~mm}$ in $30-45 \mathrm{~cm}$ and 0.16 to $0.38 \mathrm{~mm}$ in $45-60 \mathrm{~cm}$ soil depth, respectively. Treatments of $50 \%$ NPK, $100 \%$ NPK, $150 \%$ NPK, $100 \%$ $\mathrm{NPK}+\mathrm{H} . \mathrm{W}, 100 \% \mathrm{NPK}+\mathrm{Zn}, 100 \% \mathrm{NP}$, $100 \% \mathrm{~N}$ and $100 \% \mathrm{NPK}(-\mathrm{S})$ recorded significantly higher MWD than the control.

The positive effect of FYM in increasing MWD upto the deeper layers indicates that apart from direct effect of FYM as a binding agent it indirectly might have increased MWD through increased root biomass leading to higher organic matter content. Rasool et al., (2008) and Tripathi et al., (2014) also observed that application of FYM improved the MWD. The increase in organic carbon content might be responsible for stabilization of aggregates and hence higher MWD with the application of FYM and inorganic fertilizers which improves the physical condition of soil.

In conclusion, the application of optimal dose of NPK $(100 \%)$ along with FYM in ricewheat cropping system improved the soil physical properties of soil in comparison to application of NPK fertilizers alone. The physical properties play a vital role for the nutrient turnover and long-term productivity of the soil which are enhanced by balanced application of nutrients and manure. Continuous cropping of rice-wheat with imbalanced nutrient management declined the physical properties of soil. Compared with fertilizer NPK alone, use of Organic manure along with Mineral fertilizers improved soil physical properties through increased soil aggregation, improved aggregate stability, decrease in bulk density, increased saturated hydraulic conductivity and improved soil water-holding capacity for sustaining soil quality. In the light of above, it can be concluded that continuous cropping with integrated use of fertilizer and organic manure improving soil physical conditions and having positive impact of these practices on ecosystems and environment.

\section{References}

Bhatt, M.K., Raverkar, K.P., Chandra, R, Pareek, N, Singh, D.K. and Yaseen, M. 2017. Use of Inorganic Fertilizers and FYM for Twenty-Nine Years in RiceWheat Cropping System Improves Physical Soil Quality Indices after Rice. Int.J.Curr.Microbiol.App.Sci. $\quad$ 6(9): 3431-3438

Blake, G.H. and Hartge, K.H. 1986. Bulk density. In: Klute A (ed) Methods of soil analysis. Am. Soc. Agron. 2nd edn. Agron. No. 9(Part I), pp 363-375

Celik, I., Ortas, I.and Kilic, S. 2004. Effects of compost, mycorrhiza, manure and fertilizer on some physical properties of a Chromoxerert soil. Soil Till Res. 78: 59-67.

Kaje, V.V., Sharma, D.K., Shivay, Y.S., Jat, S.L., Bhatia, A., Purakayastha, T.J., Bandyopadhyay, K.K. and Bhattacharyya, R. 2018. Long-term impact of organic and conventional farming on soil physical properties under rice (Oryza sativa)-wheat (Triticum aestivum) cropping system in north-western Indo-Gangetic plains. Indian J. Agric. Sci. 88(1): 107-13

Kakraliya, S.K., Jat, R.D., Kumar, S., Choudhary, K.K., Prakash, J. and Singh, L.K. 2017. Integrated nutrient management for improving, fertilizer use efficiency, soil biodiversity and productivity of wheat in irrigated rice wheat cropping system in Indo-Gangatic plains of India. Int.J.Curr. Microbiol.App.Sci. 6(3): 152-63

Klute, A. 1965. Laboratory measurement of hydraulic conductivity of saturated soil. In: Black, C.A. ed. Methods of soil analysis. Part 3. American Society of 
Agronomy, Inc., Madison, U.S.A. pp. 933-951.

Ladha, J.K., Dawe, D., Pathak, H., Padre, A.T., Yadav, R.L., Bijay-Singh, YadvinderSingh, Singh, Y., Singh, P., Kundu, A.L., Sakal, R., Ram, N., Regmi, A.P., Gami, S.K., Bhandari, A.L., Amin, R., Yadav, C.R., Bhattarai, E.M., Das, S., Aggarwal, H.P., Gupta, R.K. and Hobbs, P.R. 2003. How extensive are yield declines in long-term rice-wheat experiments in Asia? Field Crops Res. 81: 159-180.

Nandapure, S.P., Sonune, B.A. and Patil, R.T. 2014. Long-term effects on integrated nutrient management on soil physical properties and crop productivity in sorghum-wheat cropping sequence in a vertisol. Indian J. Agric. Res. 45(4): 336-340.

Nayak, A.K., Gangwar, B., Shukla, A.K., Mazumdar, S.P., Kumar, A., Rajab, R., Kumar, A., Kumar, V., Rai, P.K. and Mohan, U. 2012. Long-term effect of different integrated nutrient management on soil organic carbon and its fractions and sustainability of ricewheat system in Indo Gangetic Plains of India. Field Crop Res. 127: 129-139.

Pant, P.K., Ram, S. and Singh, V. 2017. Yield and soil organic matter dynamics as affected by the long-term use of organic and inorganic fertilizers under ricewheat cropping system in subtropical mollisols. Agric Res. 6(4):399-409

Piper, C.S., 1950. Soil and Plant Analysis, the University of Adelaide Press, Adelaide, Australia, 368p

Rasool, R., Kukal, S.S. and Hira, G.S. 2008. Soil organic carbon and physical properties as affected by long-term application of FYM and inorganic fertilizers in maize-wheat system. Soil Till. Res., 10: 31-36.

Rudrappa, L, Purakayastha, T.J., Singh, D. and Bhadrarary, S. 2006. Long-term manuring and fertilization effects on soil organic carbon pools in a Typic Haplustept of semi-arid sub-tropical India. Soil Till Res. 88: 180-192.

Singh, G., Jalota, S.K. and Singh, Y. 2007. Manuring and residue management effects on physical properties of a soil under the rice-wheat system in Punjab, India. Soil Till Res. 94: 229-238

Singh, K.K., Jat, A.S. and Sharma, S.K. 2005. Improving productivity and profitability of rice (Oryza sativa)-wheat (Triticum aestivum) cropping system through tillage and planting management. Indian J. Agric. Sci. 7: 396-399

Tripathi, R., Nayaka, A.K., Bhattacharyya, P., Shukla, A.K., Shahid, M., Raja, R., Panda, B.B., Mohanty, S., Kumar, A., and Thilagama, V.K. 2014. Soil aggregation and distribution of carbon and nitrogen in different fractions after 41 years long-term fertilizer experiment in tropical rice-rice system. Geoderma. 213: 280-286.

Van Bavel, C.H.M. 1949. Mean weight diameter of soil aggregates as a statistical index of aggregation. Soil Sci. Soc. America Proc., 14: 20-23.

Zebarth, B. J., Neilsen, G.H., Hogue, E., and Neilsen, D. 1999. Influence of organic waste amendments on selected soil physical and chemical properties. Can $J$ Soil Sci. 79: 501-504.

\section{How to cite this article:}

Pawan Kumar Pant and Shri Ram. 2018. Long-Term Manuring and Fertilization Effects on Soil Physical Properties after Forty Two Cycles under Rice-Wheat System in North Indian Mollisols. Int.J.Curr.Microbiol.App.Sci. 7(07): 232-240. doi: https://doi.org/10.20546/ijcmas.2018.707.028 